Muhammad Nashar, Sucses Rico Manurung

\title{
Pelatihan, Gaya Kepemimpinan, terhadap Reputasi Perusahaan dengan Kinerja Karyawan sebagai Variabel Intervening (Studi pada PT Astra Graphia,Tbk di Jakarta)
}

\author{
Muhammad Nashar \\ Fakultas Ekonomi dan Bisnis, Universitas Mercubuana Jakarta \\ Sucses Riko Manurung \\ Fakultas Ekonomi dan Bisnis, Universitas Mercubuana Jakarta \\ muhammad_nashar@mercubuana.ac.id
}

\begin{abstract}
Abstrak
Penelitian ini bertujuan untuk menganalisis pengaruh Pengaruh Pelatihan dan Gaya Kepemimpinan Terhadap Reputasi Perusahaan dengan Kinerja Karyawan sebagai Variabel Intervening (Studi Kasus pada PT. Astra Graphia Jakarta). Reputasi perusahaan merupakan suatu hal yang perlu diperhatikan. Perusahaan bereputasi baik artinya perusahaan memiliki sumber daya langka dan berharga, serta merupakan sumber keunggulan daya saing. Dalam penelitian ini populasinya adalah karyawan pada PT. Astra Graphia Jakarta berjumlah 100 orang. Berdasarkan penelitian ini karena jumlah populasinya tidak lebih besar dari 100 orang responden, maka penulis mengambil $100 \%$ jumlah populasi yang ada pada PT. Astra Graphia Jakarta. Metode analisis yang digunakan adalah model analisis menggunakan PLS Versi 3. Hasil penelitian menunjukkan bahwa (1) Pelatihan berpengaruh positif dan signifikan terhadap Kinerja Karyawan, (2) Gaya Kepemimpinan tidak berpengaruh signifikan terhadap Kinerja Karyawan, (3) Pelatihan berpengaruh positif dan signifikan terhadap Reputasi Perusahaan, (4) Gaya Kepemimpinan tidak berpengaruh signifikan terhadap Reputasi Perusahaan, dan (5) Kinerja Karyawan berpengaruh positif dan signifikan terhadap Reputasi Perusahaan. Saran yang diajukan pada penelitian ini adalah PT. Astra Graphia Jakarta mengevaluasi Gaya Kepemimpinan yang diterapkan saat ini terutama mengenai sikap otoriter terhadap karyawan.
\end{abstract}

Kata Kunci: Reputasi Perusahaan, Kinerja Karyawan, Pelatihan, Gaya Kepemimpinan

\section{Pendahuluan}

Sumber daya manusia merupakan faktor yang berpengaruh terhadap kinerja dan reputasi perusahaan. Beberapa penelitian telah dilakukan terkait pengungkapan sumber daya manusia dan pengaruhnya terhadap kinerja perusahaan, khususnya yang terkait dengan perusahaan perusahaan. Sumber daya manusia (SDM) merupakan aset penting dalam suatu perusahaan, karena Sumber Daya Manusia menentukan keberhasilan suatu Perusahaan.Sumber Daya Manusia diperusahaan perlu dikelola secara profesional agar terwujud keseimbangan antara kebutuhan karyawan dengan tuntutan dan kemampuan perusahaan. Keseimbangan tersebut merupakan kunci utama perusahaan agar dapat berkembang secara produktif dan wajar (Mangkunegara, 2016).

Membangun dan mempertahankan reputasi bukanlah hal yang mudah bagi sebuah perusahaan. Menurut Serrat (2010) reputasi bukan hanya mengenai suka atau tidak, namun mengenai representasi persepsi individu atau masyarakat saat ini berdasarkan pengalamannya 


\section{Muhammad Nashar, Sucses Rico Manurung}

dimasa lampau terhadap perusahaan. Ada banyak cara yang dapat dilakukan untuk melakukan manajemen reputasi salah satunya dengan membuat strategi. (Sumarwan, 2015)

Reputasi menjadi baik atau buruk, kuat atau lemah bergantung pada kualitas pemikiran strategi, dan komitmen manajemen untuk mencapai tujuan yang telah ditetapkan, dan adanya keterampilan serta energi dengan segala komponen program yang akan direalisasikan dan di komunikasikan (Morley dalam Ardianto, 2011). Berdasarkan banyaknya pengaruh yang dihasilkan dari reputasi menjadikan penelitian ini sangat penting dilakukan karena beberapa alasan. Pertama, reputasi membantu menangkis atau meminimalkan isu negatif perusahaan dan juga serangan dari kompetitor. Perusahaan dengan reputasi yang baik memiliki kontribusi positif kepada masyarakat yang akan meragukan ketika ada isu negatif mengenai perusahaan (Anthonissen, 2008).

Terlebih dalam jasa, terjadi kontrak antara SDM dengan konsumen secara langsung. Perusahaan juga harus mengantisipasi segala kemungkinan terjadi permasalahan dalam pengelolaan SDM mulai dari tahap seleksi sampai dengan proses manajemen SDM yang lebih kompleks. Tingkat perhatian dan penekanan pada peran SDM dalam jasa adalah sangat pentin, apalagi pada era globalisasi saat ini dimana tidak akan ada batas mobilitas sumber daya termasuk SDM. Peran penting SDM dalam perusahaan jasa haru dibedakan untuk pengelolaannya lebih lanjut. Dengan melihat berbagai peran penting SDM dalam perusahaan tentunya diharapkan manajemen tidak lagi memandang sumber daya ini hanya dengan sebelah mata. Kelalaian dalam perencanaan, pengembangan, pelaksanaan serta pengawasan terhadap SDM yang dimiliki akan merugikan perusahaan.

Selain melihat perkembangan dunia teknologi dan informasi yang begitu pesat, pelatihan kinerja yang baik akan dapat membantu karyawan agar dapat lebih mengetahui dan menguasai bidang ilmu, baik yang dikuasainya atau yang akan berguna bagi karyawan dimasa mendatang. Maka karyawan perlu untuk melakukan pelatihan kerja yang akan bedampak pada keterampilan, kecakapan, dan sikap karyawan yang akan meningkat sehingga setiap pekerjaan yang menjadi tanggung jawabnya akan lebih mudah untuk diselesaikan tepat waktu yang pada akhirnya akan meningkatkan kinerja karyawan tersebut dan berdampak pada pencapaian tujuan perusahaan.

Manurut Hasibuan (2013) mendefinisikan manajemen sumber daya manusia adalah ilmu dan seni yang mengatur hubungan dan peranan tenaga kerja agar efektif dan efisien membantu terwujudnya tujuan perusahaan, karyawan dan masyarakat. Pelaksanaan kerja karyawan pada sebuah organisasi didukung oleh kualitas dari karyawan yang bersangkutan. Kualitas karyawan ditentukan dari sejauh mana keryawan sanggup menunjang tujuan perusahaan. Peningkatan skill, perubahan sikap, perilaku, koreksi terhadap kekurangan kekurangan kinerja dibutuhkan untuk mencapai tujuan perusahaan. Pelatihan akan memberikan kesempatan bagi karyawan mengembangkan keahlian dan kemampuan baru dalam bekerja agar apa yang karyawan ketahui dan kuasai saat ini maupun masa mendatang dapat membantu karyawan dalam menjalankan dan kewajibannya.

Selain Pelatihan, Gaya Kepemimpinan juga faktor yang penting untuk menimbulkan kepuasan kerja dan meningkatkan kinerja karyawan. Kepemimpinan merupakan kemampuan untuk memberikan wawasan sehingga orang lain ingin mencapainya. Pemimpin harus mampu memberikan wawasan, membangkitkan, mengembangkan serta menumbuhkan sikap hormat dan kepercayaan bawahnya. Pemberian motivasi kerja dan gaya kepemimpinan nantinya akan mempengaruhi kinerja karyawan yang positif.

Gaya Kepemimpinan adalah sekumpulan ciri yang digunakan pimpinan untuk memengaruhi bawahan agar sasaran organisasi tercapai atau dapat pula dikatakan bahwa gaya 


\section{Muhammad Nashar, Sucses Rico Manurung}

kepemimpinan adalah pola perilaku dan strategi yang disukai dan sering diterapkan oleh seorang pemimpin. Gaya kepemimpinan yang menunjukan, secara langsung maupun tidak langsung, tentang keyakinan seorang pimpinan terhadap kemampuan bawahannya. Artinya gaya kepemimpinan adalah perilaku dan strategi, sebagai hasil pemimpin ketika dia mencoba memengaruhi kinerja bawahannya. Rivai (2014)

Seorang manajer adalah seseorang yang mempunyai wewenang untuk memerintah orang lain. Seseorang yang di dalam menjalankan pekerjaannya, untuk mencapai tujuan yang telah ditetapkan, menggunakan bantuan orang lain. Dengan demikian ia perlu memimpin para karyawan. Tidak setiap orang yang ditunjuk menjadi seorang pemimpin bisa menjalankan pekerjaannya dengan baik. Tidak setiap pemimpin bisa menjadi pemimpin yang baik. Setiap pemimpin mempunyai kewajiban untuk mencapai tujuan organisasi dan memberikan perhatian terhadap kebutuhan para karyawan di bawahnya. Rivai (2014)

Tujuan perusahaan akan dapat tercapai salah satunya adalah dengan mempunyai karyawan dengan kinerja yang baik. Kinerja karyawan merupakan hasil kerja yang dicapai karyawan dalam melaksanakan tugasnya sesuai tanggung jawab yang diberikan perusahaan kepada karyawan tersebut. Maka kinerja karyawan yang baik akan berdampak pada tercapainya tujuan perusahaan, sebaliknya kinerja karyawan yang buruk dapat berdampak pada tidak tercapainya tujuan perusahaan. Menurut Simamora (2014) Pelatihan (training) merupakan proses pembelajaran yang melibatkan perolehan keahlian, konsep, peraturan, atau sikap untuk meningkatkan kinerja tenaga kerja. Menurut pasal I ayat 9 undang-undang No.13 Tahun 2003. Pelatihan kerja adalah keseluruhan kegiatan untuk memberi, memperoleh, meningkatkan, serta mengembangkan kompetensi kerja, produktivitas, disiplin, sikap, dan etos kerja pada tingkat ketrampilan dan keahlian tertentu sesuai dengan jenjang dan kualifikasi jabatan dan pekerjaan.

Menurut Sedarmayanti (2017) Kinerja merupakan terjemahan dari performance yang berarti hasil kerja seorang pekerja, sebuah proses manajemen atau suatu organisasi secara keseluruhan, dimana hasil kerja tersebut harus dapat ditunjukan buktinya secara konkrit dan dapat diukur dibandingkan dengan standar yang telah ditentukan.

PT Astra Graphia.Tbk adalah perusahaan eksklusif distributor untuk produk dan solusi Fuji Xerox di Indonesia. Astra Graphia mulai melakukan pemasaran produk Fuji Xerox dan memberikan pelayanan after salesnya semenjak tahun 1971. Hingga saat ini dengan semakin bertambahnya persaingan dan perkembangan bisnis, Astra Graphia kini menjadi salah satu market leader pada bisnis solusi perdokumenan di Indonesia.

Adapun Jenis produk dan layanan yang diberikan oleh Astra Graphia, mencakup pada ruang lingkup solusi perdokumenan dan TI (Teknologi Informasi), yang berkembang kemudian menjadi penyedia layanan berbasis perangkat keras (hardware based services) serta menjadi penyedia layanan berbasis solusi (solution based services).

Astra Graphia memiliki komitmen untuk meningkatkan kompetensi Sumber Daya Manusia (SDM). Bagi Direksi, karyawan menjadi kunci keberhasilan Perusahaan, baik untuk jangka pendek maupun jangka panjang. Seiring upaya untuk memperkuat bisnis inti dan inisiatif bisnis baru, Astra Graphia secara berkelanjutan membangun budaya inovasi di semua lini bisnis. Upaya ini juga diiringi dengan peningkatan kemampuan karyawan agar siap tumbuh bersama Perusahaan. Tahun 2019 menjadi momen percepatan peningkatan kualitas Sumber Daya Manusia untuk menyelaraskan langkah Perusahaan secara menyeluruh. Untuk itu secara konsisten, Astra Graphia melakukan program pengembangan karyawan melalui sejumlah pelatihan internal dan eksternal. Pelatihan diberikan sesuai dengan kebutuhan dan 


\section{Muhammad Nashar, Sucses Rico Manurung}

perkembangan lingkungan bisnis. Astra Graphia memberikan kesempatan yang luas kepada seluruh karyawan untuk melakukan pengembangan kompetensi.

Berdasarkan profitabilitas PT Astra Graphia.Tbk selama 3 Tahun berturut-turut mengalami penurunan. Data pada annual report tersebut menunjukkan penurunan reputasi perusahaan dikarenakan tingkat keuntungan berasarkan pengelolaan aset dan penjualan yang menurun.

Reputasi perusahaan merupakan suatu hal yang perlu diperhatikan. Perusahaan bereputasi baik artinya perusahaan memiliki sumber daya langka dan berharga, serta merupakan sumber keunggulan daya saing untuk mendapatkan above average return (Barney, 1991).Ruang lingkup reputasi perusahaan sangat luas dan secara potensial dapat menjadi keunggulan bersaing. Reputasi perusahaan diperoleh dengan mengintegrasikan beberapa pertimbangan (blends considerations) antara keuangan, manajemen, periklanan (advertising), dan hubungan masyarakat (public relations) (Maden et al., 2012).

Fenomena yang terjadi pada PT. Astra Graphia adalah penurunan kinerja karyawan selama Tahun 2018. Hal tersebut dapat dilihat melalui penilaian Key Performance Index (KPI) karyawan sebagai berikut.

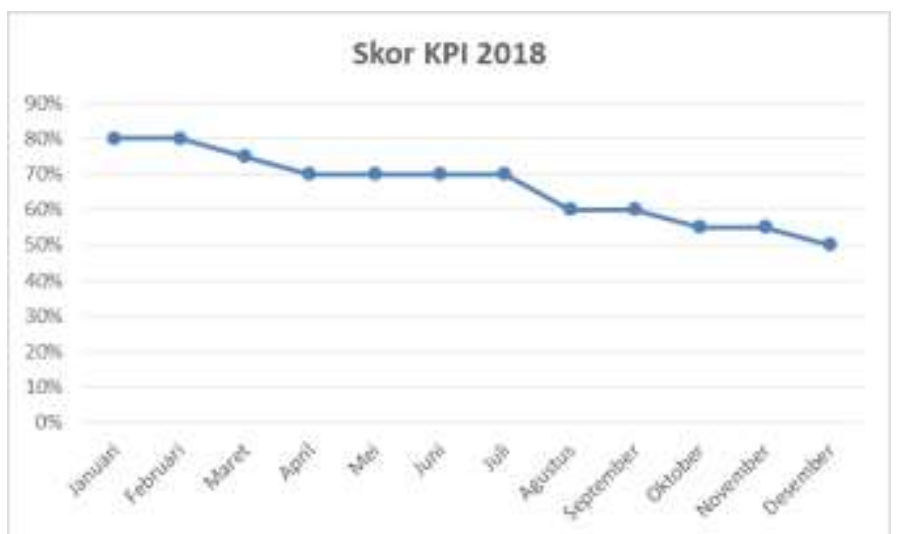

Gambar 1. Kinerja Karyawan berdasarkan Skor KPI (Sumber: HRD PT. Astra Graphia (2019))

Berdasarkan tabel diketahui bahwa terdapat penurunan kinerja karyawan PT. Astra Graphia berdasarkan Key Performance Index (KPI) perusahaan. Hal tersebut menunjukkan bahwa kinerja karyawan merupakan concern manajemen perusahaan untuk meningkatkan kinerja perusahaan secara keseluruhan.

Berikut ini disajikan tentang data jumlah karyawan Berdasarkan penelitian pendahuluan di PT Astra Graphia Tbk Jakarta, diperoleh data mengenai jumlah karyawan., seperti pada Tabel 1.4 berikut

Tabel 1. Jumlah Karyawan Berdasarkan Divisi/Jabatan PT. Astra Graphia Tbk Tahun 2019

\begin{tabular}{|l|l|l|}
\hline No & Posisi/Jabatan & Jumlah \\
\hline 1 & Manager & 1 \\
\hline 2 & Staf Adm & 10 \\
\hline 3 & Staf Sales & 20 \\
\hline 4 & Staf DGO & 4 \\
\hline 5 & Staf Ops & 7 \\
\hline 6 & Staf Analyst & 8 \\
\hline & Total & 50 \\
\hline
\end{tabular}

Sumber: Data Milik PT. Astra Graphia (2019) 
Pada Tabel 1 menunjukkan jumlah karyawan PT. Astra Graphia pada tahun 2019. Terdapat 49 orang Staf beserta rincian posisi masing-masing karyawan dan dipimpin oleh 1 orang Manajer, dimana bagian saling terkait dan saling bekerja sama untuk mengoptimalkan kinerja guna mencapai tujuan dalam memajukan perusahaan.

Dalam mendukung fenomena diatas, peneliti melakukan survei kepada 20 orang karyawan yang untuk mengetahui hal-hal apa saja menjadi faktor utama atau pemicu kinerja karyawan serta reputasi perusahaan di mata karyawan. Berikut adalah hasil Pra-survei penelitian.

Tabel 2. Faktor-Faktor yang mempengaruhi Reputasi Perusahaan

\begin{tabular}{|l|l|l|l|}
\hline No & Indikator Masalah & $\begin{array}{l}\text { Jumlah } \\
(\text { Orang })\end{array}$ & $\begin{array}{l}\text { Persentase } \\
(\%)\end{array}$ \\
\hline 1 & Kompensasi & 2 & 10 \\
\hline 2 & Gaya Kepemimpinan & 6 & 30 \\
\hline 3 & Lingkungan Kerja & 2 & 10 \\
\hline 4 & Budaya Organisasi & 1 & 5 \\
\hline 5 & Pelatihan & 9 & 45 \\
\hline Total & 20 & 100 \\
\hline
\end{tabular}

Sumber: Hasil Pra-Survei (2019)

Berdasarkan hasil Pra-Survei, diketahui bahwa faktor-faktor yang secara dominan mempengaruhi Kinerja Karyawan dan Reputasi Perusahaan adalah Pelatihan dan Gaya Kepemimpinan Hasil tersebut menjadi rujukan bagi peneliti untuk menguji faktor-faktor yang berpengaruh terhadap Reputasi Perusahaan serta Kinerja Karyawan sebagai variabel Intervening.

Selain hasil pra-survey di atas, terdapat perbedaan hasil penelitian (gap research) berhubungan dengan pengaruh Pelatihan dan Gaya Kepemimpinan terhadap Reputasi Perusahaan dengan Kinerja Karyawan sebagai Variabel Intervening.

\section{Perumusan Masalah}

1. Apakah Pelatihan berpengaruh terhadap Kinerja Karyawan PT. Astra Graphia Jakarta

2. Apakah Gaya Kepemimpinan berpengaruh terhadap Kinerja Karyawan PT. Astra Graphia Jakarta?

3. Apakah Pelatihan berpengaruh terhadap Reputasi Perusahaan PT. Astra Graphia Jakarta ?

4. Apakah Gaya Kepemimpinan berpengaruh terhadap Reputasi Perusahaan PT. Astra Graphia Jakarta?

5. Apakah Kinerja Karyawan berpengaruh terhadap Reputasi Perusahaan PT. Astra Graphia Jakarta?

\section{Tujuan Penelitian}

1) Untuk mengetahui pengaruh Pelatihan terhadap Kinerja Karyawan PT. Astra Graphia Jakarta

2) Untuk mengetahui pengaruh Gaya Kepemimpinan terhadap Kinerja Karyawan PT. Astra Graphia Jakarta 
INOBIS: Jurnal Inovasi Bisnis dan Manajemen Indonesia

Volume 02, Nomor 02, Maret 2019

Muhammad Nashar, Sucses Rico Manurung

3) Untuk mengetahui pengaruh Pelatihan terhadap Reputasi Perusahaan PT. Astra Graphia Jakarta

4) Untuk mengetahui pengaruh Gaya Kepemimpinan terhadap Reputasi Perusahaan PT. Astra Graphia Jakarta

5) Untuk mengetahui pengaruh Kinerja Karyawan terhadap Reputasi Perusahaan PT. Astra Graphia Jakarta

\section{Kajian Pustaka, Kerangka Pemikiran dan Hipotesis Pelatihan}

Menurut Sinambela (2016), pelatihan adalah serangkaian aktivitas yang dirancang untuk meningkatkan pengalaman keterampilan, keahlian, penambahan pengetahuan, serta perubahan sikap seorang individu. Peningkatan akan kemampuan dan keahlian para SDM tersebut berkaitan dengan jabatan atau fungsi yang menjadi tanggung jawabnya saat ini.

Menurut Hasibuan (2016) bahwa pelatihan merupakan suatu usaha peningkatan pengetahuan dan keahlian seorang karyawan untuk mengerjakan suatu pekerjaan tertentu. Berdasarkan ketiga definisi tersebut, maka dapat dipahami bahwa pelatihan kerja merupakan suatu pembelajaran jangka pendek untuk mengembangkan sumber daya manusia yang berkualitas. Meningkatkan pengetahuan dan keahlian seorang pegawai didalam instansi atau organisasi. Karena semakin lama pelatihan kerja dilakukan maka karyawan akan semakin mengerti akan pekerjaan yang harus dilakukan dan akan semakin meningkatkan kinerja.

Menurut The Manpower Service Commision's Glossary of Training Terms dalam Tobari (2015) mendefinisikan pelatihan sebagai suatu proses perencanaan untuk mengembangkan sikap, pengetahuan atau keahlian melalui pembelajaran untuk meningkatkan kinerja yang efektif dalam aktifitasnya.

Siagian (2015) mempertegas tentang pengertian pelatihan, ia memberikan definisi pelatihan sebagai suatu keseluruhan proses, teknik dan metode belajar mengajar dalam rerangka mengalihkan suatu pengetahuan dari seseorang kepada orang lain sesuai dengan standar yang telah ditetapkan. Untuk mencapai tujuan yang diharapkan, maka proses pelatihan harus mengandung unsur-unsur pokok kurikulum, metode dan teknik pembelajaran, instruktur (guru) dan sarana/prasarana serta dana yang memadai. Dengan demikian, pelatihan dapat didefinisikan sebagai usaha yang terencana dari organisasi untuk meningkatkan pengetahuan, keterampilan dan kemampuan pegawai.

\section{Gaya Kepemimpinan}

Secara etimologi kepemimpinan berasal dari kata dasar "pimpin" (lead) berarti bimbing atau tuntun (Hasibuan, 2016). Kepemimpinan sendiri adalah ilmu dan seni mempengaruhi orang atau kelompok untuk bertindak seperti yang diharapkan dalam rangka mencapai tujuan secara efektif dan efisien.

Gaya kepemimpinan (Leadership Style), yakni pemimpin yang menjalankan fungsi kepemimpinannya dengan segenap keterampilan dan sikapnya (Mangkunegara, 2017). Gaya kepemimpinan adalah cara seorang pemimpan bersikap, berkomunikasi, dan berinteraksi dengan orang lain dalam mempengaruhi orang untuk melakukan sesuatu. Gaya tersebut bisa berbeda - beda atas dasar motivasi, kuasa ataupun orientasi terhadap tugas atau orang tertentu.

Gaya kepemimpinan bukan suatu bakat, sehingga dapat dipelajari dan dipraktekkan dan dalam penerapannya harus disesuaikan dengan situasi yang dihadapi. Sementara itu, menurut Hamali (2016), menyatakan bahwa untuk mengetahui lebih dalam tentang gaya kepemimpinan, maka terlebih dahulu harus diketahui perbedaan antara pemimpin dan kepemimpinan. 
INOBIS: Jurnal Inovasi Bisnis dan Manajemen Indonesia

Volume 02, Nomor 02, Maret 2019

\section{Muhammad Nashar, Sucses Rico Manurung}

Pemimpin adalah orang yang memimpin suatu kelompok (dua orang atau lebih), baik pada suatu organisasi maupun keluarga.

\section{Kinerja Karyawan}

Kinerja karyawan merupakan tujuan akhir dan merupakan cara bagi manajer untuk memastikan bahwa aktivitas pegawai dan output yang dihasilkan sinergi dengan tujuan organisasi atau perusahaan. Intinya kinerja merupakan kesuksesan seseorang dalam melaksanakan suatu pekerjaan.

Menurut Ruky (2016) Kinerja karyawan adalah hasil kerja yang dicapai seseorang atau kelompok orang sesuai dengan wewenang atau tanggung jawab masing- masing karyawan selama periode tertentu. Menurut Yusuf (2015) kinerja diartikan sebagai fungsi dari interaksi antara kemampuan (ability) dan motivasi (motivation) sehingga kinerja $=\mathrm{f}(\mathrm{A} \times \mathrm{M})$. Jika ada yang tidak memadai, kinerja itu akan dipengaruhi secara negatif.

Secara lebih luas, Hasibuan (2016) menyimpulkan pengertian kinerja karyawan atau defisi kinerja atau performance sebagai hasil kinerja yang dapat dicapai oleh seseorang aau kelompok orang dalam suatu organisasi baik secara kualitatif maupun secara kuantitatif, sesuai dengan kewewenangan, tugas dan tanggung jawab masing-masing dalam upaya mencapai tujmuan organisasi bersangkutan secara legal, tidak melanggar hukum dan sesuai dengan moral ataupun etika. Berdasarkan beberapa definisi tersebut penulis menjelaskan bahwa kinerja merupakan output atau hasil kerja yang dihasilkan baik dari segi kualitas maupun kuantitas pekerjaaanya dan dapat dipertanggung jawabkan sesuai dengan peranya didalam organisasi atau perusahaan yang disertai dengan kemampuan, kecakapan, dan keterampilan dalam menyelesaikan pekerjaaanya.

Menurut Mangkunegara (2017), Kinerja seseorang di pengaruhi oleh banyak faktor yang dapat di golongkan pada 3 (tiga) kelompok yaitu kompensasi individu orang yang bersangkutan, dukungan organisasi, dan dukungan manajemen.

Menurut Nashar, et al. (2018), Kinerja adalah catatan pekerjaan seseorang sebagai keberhasilan tercapai dalam melaksanakan tugas yang diberikan kepada mereka berdasarkan keterampilan, pengalaman, pengetahuan dan tekad untuk periode waktu tertentu. Sehingga dapat dikatakan bahwa setiap karyawan mempunyai peran di dalam meningkatkan perusahaannya. Jika hal tersebut telah dimiliki oleh setiap individu diharapkan akan berkembang perasaan bertanggung jawab terhadap pekerjaannya, yang akan menumbuhkan pula kesediaan ikut berpartisipasi dalam mencapai tujuan organisasi kerjanya melalui pelaksanaan tugas-tugasnya secara maksimal.

\section{Hipotesis}

$\mathrm{H}_{1}$ : Pelatihan berpengaruh positif dan signifikan terhadap Kinerja Karyawan PT.Astra Graphia Jakarta

$\mathrm{H}_{2}$ : Gaya Kepemimpinan berpengaruh positif dan signifikan terhadap Kinerja Karyawan PT. Astra Graphia Jakarta

$\mathrm{H}_{3}$ : Pelatihan berpengaruh positif dan signifikan terhadap Reputasi Perusahaan PT. Astra Graphia Jakarta

$\mathrm{H}_{4}$ : Gaya Kepemimpinan berpengaruh positif dan signifikan terhadap Reputasi Perusahaan PT. Astra Graphia Jakarta

$\mathrm{H}_{5}$ : Kinerja Karyawan berpengaruh positif dan signifikan terhadap Reputasi Perusahaan PT. Astra Graphia Jakarta 
INOBIS: Jurnal Inovasi Bisnis dan Manajemen Indonesia

Volume 02, Nomor 02, Maret 2019

Muhammad Nashar, Sucses Rico Manurung

\section{Metode Penelitian}

\section{Waktu dan Tempat Penelitian}

Penelitian ini dilakukan di PT. Astra Graphia Jakarta yang beralamat di Jl. Kramat Raya No.43, RT.3/RW.4, Kramat, Kec. Senen, Kota Jakarta Pusat, Daerah Khusus Ibukota Jakarta 10450. Adapun penelitian ini dimulai pada Bulan April 2019 - Desember 2019.

\section{Desain Penelitian}

Desain Penelitian adalah rancangan penelitian yang akan digunakan sebagai pedoman untuk melakukan proses penelitian. Dalam penelitian ini desain penelitian yang digunakan adalah desain penelitian kausal. Menurut Sugiyono (2016) penelitian kausal adalah penelitian yang bertujuan untuk mengetahui tentang hubungan yang bersifat sebab dan akibat karena adanya variabel independen (variabel bebas) dan variabel dependent (variabel terikat).

Desain penelitian ini berguna untuk mengetahui apakah ada pengaruh antara variabel bebas dalam hal ini adalah Pelatihan dan Gaya Kepemimpinan terhadap variabel terikat yaitu Reputasi Perusahaan serta Kinerja Karyawan sebagai variabel Intervening. Pendekatan yang dilakukan pada penelitian ini adalah dengan menggunakan pendekatan kuantitatif. Menurut Sugiyono (2016), pendekatan kuantitatif merupakan metode untuk menguji teori-teori tertentu dengan cara meneliti hubungan antar variabel. Antar keseluruhan variabel-variabel ini diukur sehingga data-data yang terdiri dari angka-angka dapat dianalisis berdasarkan prosedur statistik.

\section{Skala Pengukuran Variabel}

Skala ordinal memungkinkan untuk pengurutan data dari tingkat yang paling rendah ke tingkat paling tinggi atau sebaliknya, dengan interval tidak harus sama. Skala pengukuran ordinal memberikan informasi tentang jumlah relatif karakteristik berbeda yang dimiliki oleh objek atau individu tertentu (Ghozali dan Hengky, 2015). Pengukuran masing-masing variabel dalam penelitian ini menggunakan skala likert. Skala likert merupakan metode yang digunakan untuk mengukur sikap, pendapat dan persepsi kelompok orang tentang fenomena sosial (Sugiyono, 2016).

Bahwa skala yang digunakan pada kuesioner untuk mendapatkan data responden adalah 1-5 yang mewakili jawaban tiap responden dan diujikan pengaruhnya terhadap Kinerja Perusahaan dan Reputasi Perusahaan untuk menjawab rumusan masalah.

\section{Populasi dan Sampel}

Menurut Sugiyono (2016) populasi adalah wilayah generalisasi yang terdiri atas objek dan subjek yang mempunyai kualitas dan karakteristik tertentu yang ditetapkan oleh peneliti untuk dipelajari dan kemudian ditarik kesimpulannya. Dapat disimpulkan populasi adalah pengamatan yang dilakukan oleh peneliti untuk mencari kesimpulan dari penelitian tersebut. Populasi dapat memudahkan peneliti dalam penelitiannya. Dalam penelitian ini populasinya adalah karyawan pada PT. Astra Graphia Jakarta berjumlah 100 orang.

Sampel adalah bagian dari jumlah dan karakteristik yang dimiliki oleh populasi tersebut (Sugiyono, 2016). Pengambilan sampel ditujukan kepada karyawan PT. Astra Graphia Jakarta. Menurut Arikunto (2013), jika jumlah populasinya kurang dari 100 orang, maka jumlah sampelnya diambil secara keseluruhan, tetapi jika populasinya lebih besar dari 100 orang, maka bisa diambil $10-15 \%$ atau 20-25\% dari jumlah populasinya. Berdasarkan penelitian ini karena jumlah populasinya tidak lebih besar dari 100 orang responden, maka penulis mengambil 100\% jumlah populasi yang ada pada PT. Astra Graphia Jakarta sebanyak 100 responden. Dengan 


\section{Muhammad Nashar, Sucses Rico Manurung}

demikian penggunaan seluruh populasi tanpa harus menarik sampel penelitian sebagai unit observasi disebut sebagai teknik sensus/sampel jenuh (Sugiyono, 2016).

\section{Hasil dan Pembahasan}

\section{Analisis Analisis Partial Least Square}

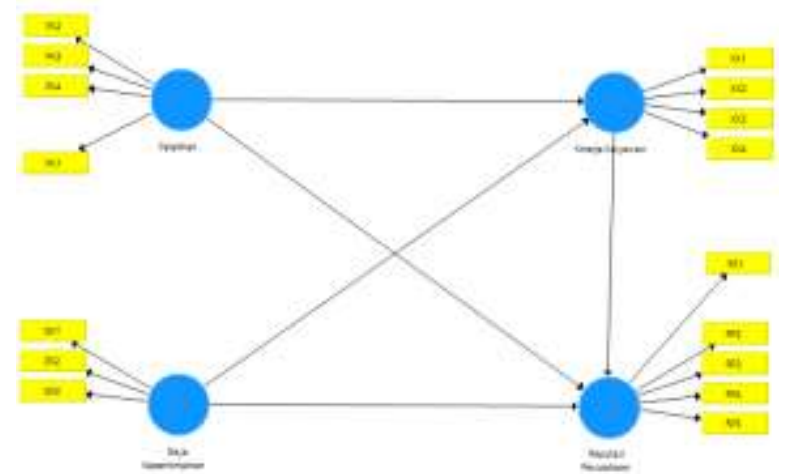

Gambar 2. Evaluasi Model Pengukuran (Outer Model) (Sumber: Output PLS 3.0, Data Diolah (2019))

\section{Convergent Validity}

Suatu indikator dinyatakan valid jika pengukuran loading factor di atas 0,70 sehingga bila ada loading factor dibawah 0,70 maka akan di drop dari model (Ghozali, 2014). Pengujian validitas untuk indikator reflektif menggunakan korelasi antara skor item dengan skor konstruknya. Pengukuran dengan indikator reflektif menunjukkan adanya perubahan pada suatu indikator dalam suatu konstruk jika indikator lain pada konstruk yang sama berubah (atau dikeluarkan dari model).

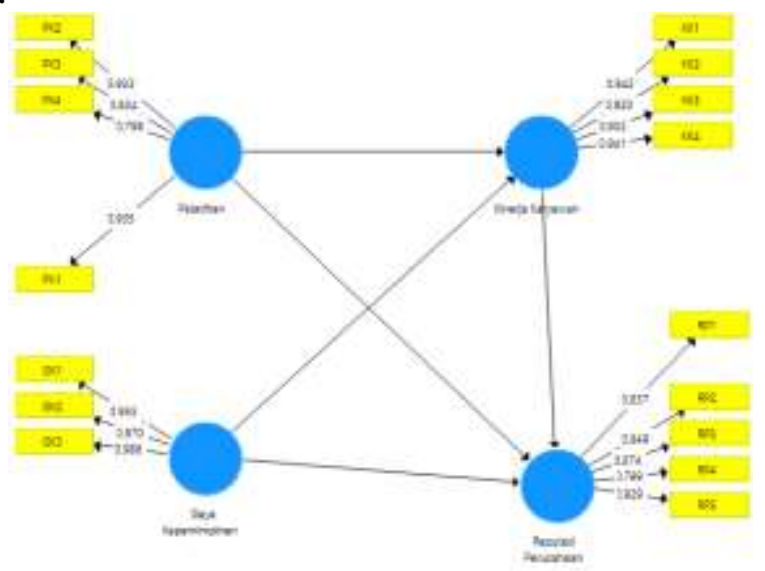

Gambar 3. Hasil Output Diagram (Sumber: Output PLS 3.0, Data Diolah (2019))

Pada Gambar di atas dapat dilihat besaran loading factor hasil estimasi ulang tersebut menunjukan bahwa seluruh indikator telah memiliki validitas yang baik karena memiliki loading factor lebih dari 0,7.

Berdasarkan gambar diketahui bahwa seluruh dimensi telah memenuhi kategori validitas. Hal tersebut dikarenakan seluruh dimensi memiliki nilai Loading Factor di atas 0,70. Selain nilai Loading Factor, untuk menganalisis validitas data penelitian dapat menggunakan nilai Average Variance Extracted (AVE). 


\section{Uji Convergent Validity}

Pengukuran lain yang juga digunakan untuk menguji reliabilitas adalah AVE. nilai AVE bertujuan untuk mengukur tingkat variansi suatu komponen konstruk yang dihimpun dari indikatornya dengan menyesuaikan pada tingkat kesalahan. Nilai AVE minimal yang direkomendasikan adalah 0,5 (Ghozali, 2015). Output AVE yang diperoleh dapat di lihat pada

Tabel 3. Hasil Pengujian AVE(Average Variance Extracted)

\begin{tabular}{|l|l|l|}
\hline Variabel & $\begin{array}{l}\text { AVE (Average Variance } \\
\text { Extracted) }\end{array}$ & Keterangan \\
\hline Gaya Kepemimpinan & 0.943 & Valid \\
\hline Kinerja Karyawan & 0.872 & Valid \\
\hline Pelatihan & 0.770 & Valid \\
\hline Reputasi Perusahaan & 0.737 & Valid \\
\hline
\end{tabular}

Sumber: Output PLS Versi 3, Data Diolah

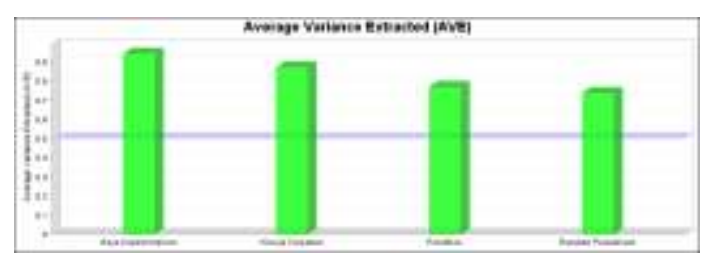

Gambar 4. Grafik Average Variance Extracted (AVE) (Sumber: output PLS Versi 3, Data Diolah)

Berdasarkan Tabel dan gambar, diketahui bahwa seluruh variabel penelitian valid. Hal tersebut dikarenakan nilai AVE berada di atas ketentuan sebesar 0,50 (Ghozali dan Hengky, 2015).

Tabel 4. Uji Discriminant Validity

\begin{tabular}{|l|l|l|l|l|}
\hline & Gaya Kepemimpinan & $\begin{array}{l}\text { Kinerja } \\
\text { Karyawan }\end{array}$ & Pelatihan & $\begin{array}{l}\text { Reputasi } \\
\text { Perusahaan }\end{array}$ \\
\hline Gaya Kepemimpinan & $\mathbf{0 . 9 7 1}$ & & & \\
\hline Kinerja Karyawan & 0.586 & $\mathbf{0 . 9 3 4}$ & & \\
\hline Pelatihan & 0.831 & 0.736 & $\mathbf{0 . 8 7 7}$ & \\
\hline Reputasi Perusahaan & 0.612 & 0.837 & 0.772 & $\mathbf{0 . 8 5 9}$ \\
\hline
\end{tabular}

Sumber: output PLS Versi 3, Data Diolah

Pada Tabel dapat dilihat nilai AVE variabel korelasi Reputasi Perusahaan sebesar 0.859. Nilai tersebut lebih besar daripada nilai korelasi variabel Reputasi Perusahaan dengan variabel lainnya. Dengan demikian syarat discriminant validity melalui uji Fornell-Lacker Criterion telah terpenuhi.Selain uji Fornell-Lacker, discriminant validity juga dapat diuji berdasarkan nilai Cross Loading.

Suatu indikator dinyatakan memenuhi discriminant validity apabila nilai cross loading dimensi pada variabelnya adalah yang terbesar dibandingkan pada variabel lainnya (Ghozali, 2014). Berikut adalah hasil nilai cross loading. 
INOBIS: Jurnal Inovasi Bisnis dan Manajemen Indonesia

Volume 02, Nomor 02, Maret 2019

Muhammad Nashar, Sucses Rico Manurung

Tabel 5. Hasil Nilai Cross Loading

\begin{tabular}{|l|l|l|l|l|}
\hline \multirow{2}{*}{ Dimensi } & Variabel & \multicolumn{4}{|l|}{} \\
\cline { 2 - 5 } & Gaya Kepemimpinan & Kinerja Karyawan & Pelatihan & $\begin{array}{l}\text { Reputasi } \\
\text { Perusahaan }\end{array}$ \\
\hline GK1 & 0.955 & 0.558 & 0.804 & 0.559 \\
\hline GK2 & 0.970 & 0.531 & 0.797 & 0.584 \\
\hline GK3 & 0.988 & 0.613 & 0.819 & 0.637 \\
\hline KK1 & 0.538 & 0.942 & 0.654 & 0.790 \\
\hline KK2 & 0.502 & 0.920 & 0.631 & 0.796 \\
\hline KK3 & 0.568 & 0.932 & 0.750 & 0.752 \\
\hline KK4 & 0.579 & 0.941 & 0.709 & 0.789 \\
\hline PK1 & 0.751 & 0.720 & 0.935 & 0.727 \\
\hline PK2 & 0.695 & 0.714 & 0.933 & 0.699 \\
\hline PK3 & 0.609 & 0.584 & 0.834 & 0.714 \\
\hline PK4 & 0.900 & 0.545 & 0.898 & 0.553 \\
\hline RP1 & 0.688 & 0.699 & 0.817 & 0.837 \\
\hline RP2 & 0.559 & 0.676 & 0.707 & 0.849 \\
\hline RP3 & 0.436 & 0.689 & 0.601 & 0.874 \\
\hline RP4 & 0.391 & 0.687 & 0.510 & 0.799 \\
\hline RP5 & 0.529 & 0.829 & 0.653 & 0.929 \\
\hline
\end{tabular}

Sumber: Output PLS versi 3, data diolah

Berdasarkan tabel, diketahui bahwa dimensi pada suatu variabel memiliki nilai lebih besar dibandingkan dengan nilai dimensi lainnya pada satu kolom. Dengan demikian syarat discriminant validity telah terpenuhi.

\section{Uji Reliabilitas}

Tabel 6. Hasil Pengujian CR (Composite Reliability)

Sumber: Output PLS Versi 3, Data Diolah

\begin{tabular}{|l|l|l|}
\hline Variabel & $\begin{array}{l}\text { CR (Composite } \\
\text { Reliability) }\end{array}$ & Keterangan \\
\hline Gaya Kepemimpinan & 0.980 & Reliable \\
\hline Kinerja Karyawan & 0.965 & Reliable \\
\hline Pelatihan & 0.930 & Reliable \\
\hline Reputasi Perusahaan & 0.933 & Reliable \\
\hline
\end{tabular}

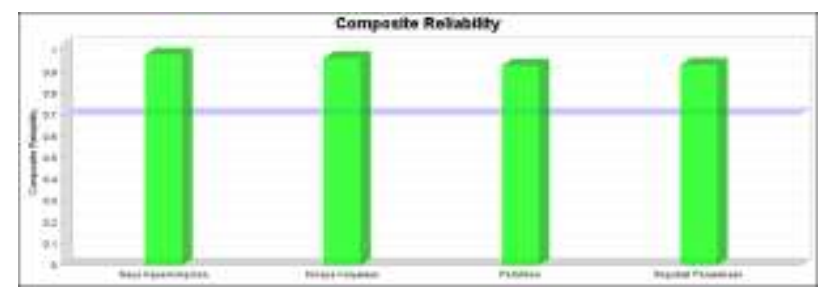

Gambar 5. Grafik Composite Reliability (CR) (Sumber: Output PLS Versi 3, Data Diolah)

Berdasarkan tabel dan Gambar, terlihat bahwa semua konstruk dalam penelitian dinyatakan Reliabel dikarenakan nilai Composite Reliability untuk semua konstruk adalah di atas 0,70 (Ghozali dan Hengky, 2015). 
INOBIS: Jurnal Inovasi Bisnis dan Manajemen Indonesia

Volume 02, Nomor 02, Maret 2019

Muhammad Nashar, Sucses Rico Manurung

Tabel 7. Hasil Pengujian CA (Cronbach Alpha)

\begin{tabular}{|l|l|l|}
\hline Variabel & CA (Cronbach Alpha) & Keterangan \\
\hline Gaya Kepemimpinan & 0.970 & Reliable \\
\hline Kinerja Karyawan & 0.951 & Reliable \\
\hline Pelatihan & 0.899 & Reliable \\
\hline Reputasi Perusahaan & 0.910 & Reliable \\
\hline
\end{tabular}

Sumber: Output PLS Versi 3, Data Diolah

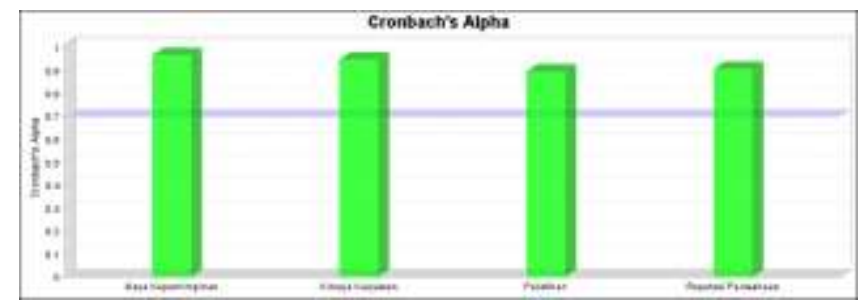

Gambar 6. Grafik Cronbach's Alpha (CA) (Sumber: Output PLS Versi 3, Data Diolah)

Berdasarkan gambar dan tabel, terlihat bahwa semua konstruk dalam penelitian dinyatakan Reliabel dikarenakan nilai Cronbach's Alpha untuk semua konstruk sudah memenuhi syarat yaitu adalah di atas 0,70 .

\section{Hasil Pengujian Model Struktural (Inner Model) Hasil Uji Koefisien Determinasi $\left(\mathbf{R}^{2}\right)$}

Tabel 8. Hasil Uji Koefisien Determinasi

\begin{tabular}{|l||l|}
\hline & R Square \\
\hline Kinerja Karyawan & 0.543 \\
\hline Reputasi Perusahaan & 0.754 \\
\hline Sumber: Output PLS Versi 3, Data Diolah
\end{tabular}

Berdasarkan Tabel, terlihat bahwa nilai R-Square untuk konstruk Kinerja Karyawan adalah 0.543 dan Reputasi Perusahaan sebesar 0.754. Hal ini juga berarti variabilitas Kinerja Karyawan dan Reputasi Perusahaan dapat dijelaskan oleh kedua variabel dalam model yaitu Pelatihan dan Gaya Kepemimpinan sebesar 54,3\% dan 75,4\%.

Nilai Predictive Relevance $\left(\mathrm{Q}^{2}\right)$

Tabel 9. Hasil Uji Nilai Predictive Relevance $\left(\mathrm{Q}^{2}\right)$

\begin{tabular}{|l|l|l|l|}
\hline & SSO & SSE & $\mathrm{Q}^{2}(=1-\mathrm{SSE} / \mathrm{SSO})$ \\
\hline Gaya Kepemimpinan (X2) & 500.000 & 500.000 & \\
\hline Kinerja Karyawan (Y1) & 400.000 & 185.320 & $\mathbf{0 . 5 3 7}$ \\
\hline Pelatihan (X1) & 600.000 & 600.000 & \\
\hline Reputasi Perusahaan (Y2) & 800.000 & 359.300 & $\mathbf{0 . 5 5 1}$ \\
\hline
\end{tabular}

Sumber: Output PLS Versi 3, Data Diolah

Berdasarkan perhitungan predictive relevance $\left(\mathrm{Q}^{2}\right)$ pada tabel 4.19 menunjukkan nilai sebesar 0.537 dan 0.551 , dapat disimpulkan bahwa model memiliki nilai prediktif yang relevan. 
INOBIS: Jurnal Inovasi Bisnis dan Manajemen Indonesia

Volume 02, Nomor 02, Maret 2019

Muhammad Nashar, Sucses Rico Manurung

\section{Evaluasi Model Fit}

Evaluasi model fit dalam penelitian ini dilakukan menggunakan model pengujian normal fit index (NFI) yang dikemukakan oleh Ghozali dan Hengky (2015).

Tabel 10. Hasil Uji Model Fit

\begin{tabular}{|l|l|l|}
\hline & Saturated Model & Estimated Model \\
\hline NFI & 0.715 & 0.715 \\
\hline
\end{tabular}

Sumber: Output PLS Versi 3, Data Diolah

Berdasarkan tabel, hasil penelitian menunjukkan bahwa nilai saturated model (measurement) fit dan nilai estimated model (structural model) fit memiliki nilai yang sama. Dari hasil tersebut dapat disimpulkan bahwa model dalam penelitian ini memiliki nilai normal fit index (NFI) yang menunjukkan bahwa model dalam penilitian ini 71,5\% (0.715) lebih baik dari pada null model.

\section{Hasil Uji Signifikansi atau Uji t-Statistics}

t-Statistic (Bootstraping) digunakan untuk melihat yang nilai signifikansi antar konstruk Untuk melihat hasil signifikansi dari koefisien parameter dapat dihitung dari dimensi variabel yang telah valid. Peneliti ingin mengetahui terdapat pengaruh positif atau negatif dan signifikan atau tidak signifikan berdasarkan perhitungan $\mathrm{P}$ Values yang harus dibawah 0,05 dan t statistik lebih besar sama dengan 1,96 (Ghozali dan Hengky, 2015).

\section{Hasil Bootstraping}

Dalam Smart PLS, pengujian setiap hubungan dilakukan dengan menggunakan simulasi dengan metode bootstrapping terhadap sampel. Berikut hasil pengujian dengan metode bootstrapping pada model penelitian

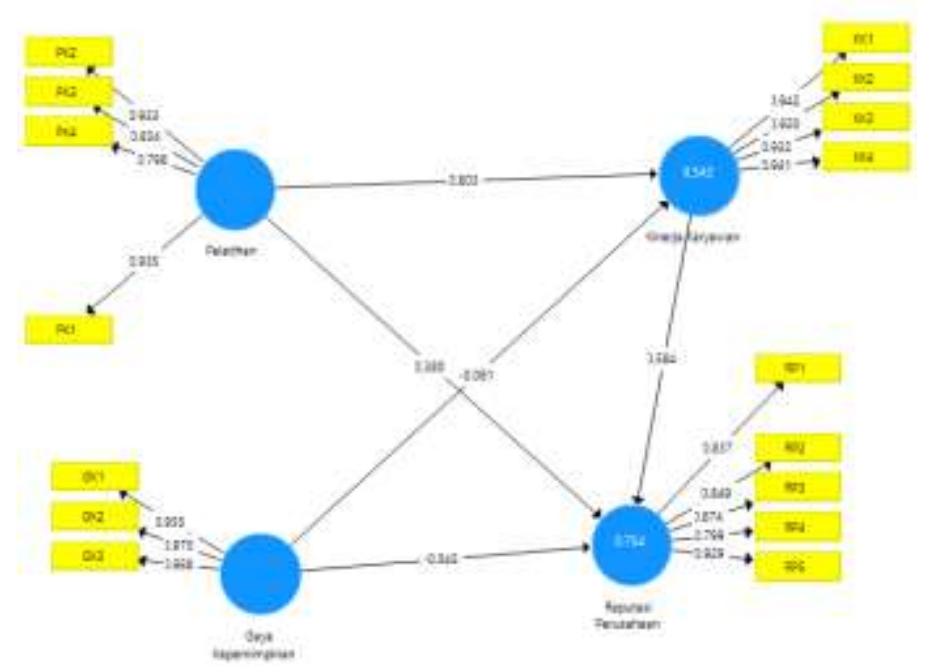

Gambar 7. Hasil Uji Bootstrapping 


\section{Uji Hipotesis (Path Coefficient)}

Berdasarkan hasil bootstrapping maka dapat diringkas dalam Tabel 11 di bawah ini. Adapun untuk menguji hipotesis dapat dilakukan dengan melihat nilai t-statistik dan nilai probabilitas.

Tabel 11. Hasil Uji Signifikansi Antar Variabel (Bootstrapping)

\begin{tabular}{|l|l|l|l|}
\hline & $\begin{array}{l}\text { Original Sample } \\
(\mathrm{O})\end{array}$ & $\begin{array}{l}\text { T Statistics } \\
(\mid \mathrm{O} / \mathrm{STDEV})\end{array}$ & P Values \\
\hline Gaya Kepemimpinan -> Kinerja Karyawan & -0.081 & 0.820 & 0.413 \\
\hline Gaya Kepemimpinan -> Reputasi Perusahaan & -0.045 & 0.539 & 0.590 \\
\hline Kinerja Karyawan -> Reputasi Perusahaan & 0.584 & 6.062 & 0.000 \\
\hline Pelatihan -> Kinerja Karyawan & 0.803 & 8.930 & 0.000 \\
\hline Pelatihan -> Reputasi Perusahaan & 0.380 & 2.930 & 0.004 \\
\hline
\end{tabular}

Sumber: Output PLS versi 3, data diolah

\section{Pembahasan}

\section{Pengaruh Pelatihan terhadap Kinerja Karyawan}

Berdasarkan hasil penelitian, diketahui bahwa Pelatihan berpengaruh positif dan signifikan terhadap Kinerja Karyawan. Hal tersebut dikarenakan nilai t statistik sebesar 8.930 $>1.96$ (Ghozali dan Hengky, 2015) sehingga dapat dikatakan berpengaruh signifikan.

Organisasi yang efektif harus mampu untuk menemukan, mendayagunakan, mempertahankan, dan mengembangkan manusia untuk mencapai hasil yang dicita-citakan (Mangkunegara, 2016). Dapat disimpulkan bahwa tercapainya tujuan perusahaan sangat ditentukan oleh usaha manusianya, baik dalam kegiatan perencanaan, pengorganisasian, pengarahaan, pengkoordinasian dan pengendalian. Sumber daya manusia di perusahaan berperan sebagai penentu keberhasilan perusahaan untuk mencapai hasil yang dicitacitakan (Kaswan, 2015).

Salah satu cara untuk mengembangkan kinerja yang dimiliki oleh karyawan di perusahaan adalah diadakannya suatu program pelatihan dimana program yang diterapkan tersebut dibuat sesuai kebutuhan dari perusahaan (Sudarmanto, 2015). Pelatihan adalah proses pembelajaran keterampilan dasar yang dibutuhkan oleh karyawan baru untuk melaksanakan pekerjaan (Hamali, 2016). Hasil penelitian ini sejalan dengan penelitian sebelumnya yang dilakukan oleh Purba (2016) dan Widijanto (2017) bahwa Pelatihan berpengaruh positif dan signifikan terhadap Kinerja Karyawan.

\section{Pengaruh Gaya Kepemimpinan terhadap Kinerja Karyawan}

Berdasarkan hasil penelitian, diketahui bahwa Gaya Kepemimpinan tidak berpengaruh signifikan terhadap Kinerja Karyawan. Hal tersebut dikarenakan nilai t statistik sebesar 0.820 $<1.96$ (Ghozali dan Hengky, 2015) sehingga dapat dikatakan tidak berpengaruh signifikan. Gaya kepemimpinan merupakan norma perilaku yang digunakan oleh seseorang pada saat orang tersebut mencoba mempengaruhi perilaku orang lain seperti yang ia lihat (Yukl, 2015).

Seorang pemimpin harus menyadari bahwa Sumber Daya Manusia merupakan faktor kunci yang paling banyak berpengaruh terhadap produktivitas perusahaan. Perusahaan menuntut para pekerjanya untuk bekerja secara optimal dalam memenuhi kebutuhan perusahaan, disamping itu perusahaan harus dapat memenuhi kebutuhan setiap karyawannya. Berdasarkan hasil penelitian, dapat disimpulkan bahwa Gaya Kepemimpinan bukanlah faktor 


\section{Muhammad Nashar, Sucses Rico Manurung}

yang dipertimbangkan bagi karyawan untuk meningkatkan kinerjanya. Dengan kata lain, Gaya Kepemimpinan yang diterapkan saat ini pada PT. Astra Graphia belum memberikan dampak bagi peningkatan kinerja (Rompas, et al, 2018). Hasil penelitian ini sejalan dengan penelitian sebelumnya yang Rompas, et al (2018) serta Kusuma, et al (2019) bahwa Gaya Kepemimpinan tidak berpengaruh signifikan terhadap Kinerja Karyawan.

\section{Pengaruh Pelatihan terhadap Reputasi Perusahaan}

Hasil penelitian menunjukkan bahwa pelatihan berpengaruh positif dan signifikan terhadap Reputasi Perusahaan. Hal tersebut dikarenakan nilai t statistik sebesar $2.903>1.96$ (Ghozali dan Hengky, 2015) sehingga dapat dikatakan berpengaruh signifikan. Pelatihan adalah serangkaian aktivitas yang dirancang untuk meningkatkan pengalaman keterampilan, keahlian, penambahan pengetahuan, serta perubahan sikap seorang individu (Sinambela, 2017). Menurut Manning (2015) beberapa praktik pelatihan dapat digunakan untuk meningkatkan kinerja pekerjaan karyawan, yang menghasilkan peningkatan kinerja organisasi atau perusahaan secara keseluruhan. Dengan demikian, praktik pelatihan dapat menjadi faktor utama bagi keberhasilan suatu perusahaan. Pengaruh manajemen sumber daya manusia dan praktik pelatihan pada kinerja organisasi telah menjadi topik penelitian penting baru-baru ini (Treven, et al, 2015).

Melalui program pelatihan yang tepat, kinerja karyawan akan meningkat sehingga reputasi organisasi akan semakin baik (Harahap dan Anita, 2016). Oleh karena itu, pelatihan merupakan sesuatu yang memberikan dampak signifikan terhadap Reputasi Organisasi. Hasil penelitian ini sejalan dengan penelitian sebelumnya yang dilakukan oleh Widijanto (2017) bahwa Pelatihan berpengaruh positif dan signifikan terhadap Reputasi Perusahaan

\section{Pengaruh Gaya Kepemimpinan terhadap Reputasi Perusahaan}

Berdasarkan hasil penelitian, diketahui bahwa Gaya Kepemimpinan tidak berpengaruh signifikan terhadap Reputasi Perusahaan. Hal tersebut dikarenakan nilai t statistik sebesar $0.539<1.96$ (Ghozali dan Hengky, 2015) sehingga dapat dikatakan tidak berpengaruh signifikan. Menurut Alfalah (2017) selama beberapa dekade yang lalu, konsep kepemimpinan telah ditemukan sebagai fokus area bagi para sarjana dan praktisi dari berbagai bidang ilmiah, sebagian besar penelitian kepemimpinan berfokus pada dampak para pemimpin dalam keberhasilan dan pengembangan manusia.

Hasil penelitian menunjukkan bahwa Gaya Kepemimpinan tidak memberikan dampak terhadap Reputasi Organisasi. Hal tersebut menunjukkan bahwa Kepemimpinan yang diterapkan pada PT. Astra Graphia belum mampu menjadi pedoman bagi karyawan untuk bekerja sesuai visi dan misi perusahaan (Mousavi, et al, 2015). Seorang pimpinan yang baik, harus mampu menjelaskan visi dan misi perusahaan secara sederhana kepada karyawan sehingga karyawan mengerti fungsi dan tugasnya masing-masing untuk mencapai tujuan perusahaan. Pimpinan yang lemah akan berdampak pada kinerja karyawan yang stagnan dan menurunkan reputasi perusahaan (Conte, 2018). Hasil penelitian ini sejalan dengan penelitian sebelumnya yang dilakukan oleh Conte (2018) bahwa Gaya Kepemimpinan tidak berpengaruh signifikan terhadap Reputasi Perusahaan.

\section{Pengaruh Kinerja Karyawan terhadap Reputasi Perusahaan}

Hasil penelitian menunjukkan bahwa Kinerja Karyawan berpengaruh positif dan signifikan terhadap Reputasi Perusahaan. Hal tersebut dikarenakan nilai t statistik sebesar $6.062>1.96$ (Ghozali dan Hengky, 2015) sehingga dapat dikatakan berpengaruh signifikan. 


\section{Muhammad Nashar, Sucses Rico Manurung}

Sasaran strategis yang harus dicapai sebuah perusahaan dapat tercapai jika kinerja karyawan dapat dimaksimalkan. Menurut Chou, et al (2015) untuk memenuhi apa yang diharapkan konsumen hanya dapat dicapai jika perusahaan dapat mengalokasikan dan mengkoordinasikan sumber daya manusia yang dimiliki secara efektif dan efisien. Dengan kinerja karyawan yang maksimal melalui pelayanan dan kemampuan menjalin hubungan baik dengan konsumen, hal tersebut akan membangun reputasi perusahaan yang diharapkan secara signifikan (Suher, et al, 2017). Hasil penelitian ini sejalan dengan penelitian sebelumnya yang dilakukan oleh Nguyen and Gaston (2018) bahwa Kinerja Karyawan berpengaruh positif dan signifikan terhadap Reputasi Perusahaan.

\section{Kesimpulan dan Saran \\ Kesimpulan}

1. Berdasarkan hasil penelitian, diketahui bahwa Pelatihan berpengaruh positif dan signifikan terhadap Kinerja Karyawan. Salah satu cara untuk mengembangkan kinerja yang dimiliki oleh karyawan di perusahaan adalah diadakannya suatu program pelatihan dimana program yang diterapkan tersebut dibuat sesuai kebutuhan dari perusahaan

2. Berdasarkan hasil penelitian, diketahui bahwa Gaya Kepemimpinan tidak berpengaruh signifikan terhadap Kinerja Karyawan. Gaya Kepemimpinan yang diterapkan saat ini pada PT. Astra Graphia belum memberikan dampak bagi peningkatan kinerja

3. Hasil penelitian menunjukkan bahwa pelatihan berpengaruh positif dan signifikan terhadap Reputasi Perusahaan. Melalui program pelatihan yang tepat, kinerja karyawan akan meningkat sehingga reputasi organisasi akan semakinbaik

4. Berdasarkan hasil penelitian, diketahui bahwa Gaya Kepemimpinan tidak berpengaruh signifikan terhadap Reputasi Perusahaan. Kepemimpinan yang diterapkan pada PT. Astra Graphia belum mampu menjadi pedoman bagi karyawan untuk bekerja sesuai visi dan misi perusahaan

5. Hasil penelitian menunjukkan bahwa Kinerja Karyawan berpengaruh positif dan signifikan terhadap Reputasi Perusahaan. Dengan kinerja karyawan yang maksimal melalui pelayanan dan kemampuan menjalin hubungan baik dengan konsumen, hal tersebut akan membangun reputasi perusahaan yang diharapkan secara signifikan

\section{Saran}

Berdasarkan kesimpulan di atas, berikut adalah saran yang diajukan pada penelitian ini.

1. Saran untuk perusahaan dan karyawan PT. Astra Graphia

1) PT. Astra Graphia disarankan mengevaluasi kembali materi pelatihan yang akan diberikan untuk memastikan materi tersebut sesuai dengan kebutuhan karyawan dalam pekerjaan dan pengembangan karirnya

2) PT. Astra Graphia disarankan memberi masukkan bagi tiap pimpinan untuk lebih dekat dengan bawahan dalam hal ini pimpinan harus bersedia membimbing karyawan yang mengalami kesulitan ketika bekerja. Selain itu, pimpinan harus dapat mendengar keluhan karyawan dan menjadi tempat konsultasi bagi para karyawan.

3) PT. Astra Graphia disarankan kembali meninjau penilaian Key Performance Index karyawan berdasarkan waktu kerja. Hal tersebut dimaksudkan agar pekerjaan karyawan dapat diselesaikan tepat waktu dan menjadi dasar penilaian perusahaan terhadap prestasi karyawan. 
2. Saran untuk penelitian selanjutnya

Disarankan pada penelitian selanjutnya menggunakan variabel-variabel lain yang diujikan terhadap Kinerja Karyawan dan Reputasi Perusahaan. Hal tersebut dimaksudkan untuk mendapatkan hasil yang lebih komprehensif di masa mendatang. Selain itu, disarankan pada penelitian selanjutnya dapat mengkaji kembali beberapa pernyataan pada indikatorindikator yang digunakan pada penelitian ini untuk mendapatkan kajian yang lebih komprehensif mengenai pernyataan-pernyataan yang diberikan kepada responden dalam bentuk kuesioner.

\section{Daftar Pustaka}

Achmadi. 2017. "Analisis Variabel-Variabel yang Mempengaruhi Reputasi Perusahaan untuk Membangun Kepercayaan dan Minat Beli Konsumen”. Jurnal Administrasi Bisnis. Vol. 4 No. 4.

Alfalah, Tasneem F. 2017. "The Role of Leadership Styles In Building and Sustaining Corporate Reputation - Empirical Investigation on Islamic Banks in Jordan". Review of Management and Marketing. Vol. 7 No. 3.

Alma, Buchari. 2016. Manajemen Pemasaran dan Pemasaran Jasa. Banndung: Penerbit Alfabeta.

Al-Mzary, Maaly Mefleh Mohammed., Abedallah Mohammad Hani., D.A Al-rifai., and Mohammed Omer Eid AlMomany. 2015. "Training and its Impact on the Performance of Employees at Jordanian Universities from the Perspective of Employees: The Case of Yarmouk University". Journal of Education and Practice. Vol. 6 No. 32.

Arikunto, S. 2013. Prosedur Penelitian: Suatu Pendekatan Praktik. Jakarta: Rineka Cipta.

Barney, J. B. 1991. "Firm Resources and Sustained Competitive Advantage." Journal of Management. Vol. 17.

Bintoro dan Daryanto. 2017. Manajemen Penilaian Kinerja Karyawan. Yogyakarta: Penerbit Gaya Media.

Buchari, Alma. 2016 Manajemen Pemasaran dan Pemasaran Jasa. Bandung. Alfabeta.

Conte, Francesca. 2018. "Understanding the Influence of CEO Tenure and CEO Reputation on Corporate Reputation: An Exploratory Study in Italy". International Journal of Business and Management. Vol. 13 No. 3

Fahmi, Irham. 2016. Perilaku Organisasi: Teori, Aplikasi, dan Kasus. Cetakan Kedua. Bandung: CV. Alfabeta. Anggota IKAPI.

Ghozali, Imam, Hengky Latan. 2015. Konsep, Teknik, Aplikasi Menggunakan Smart PLS 3.0 Untuk Penelitian Empiris. Semarang: BP Undip.

Gozukara, Izlem and Osman Yildirim. 2015. "The Effect of Perceived Corporate Reputation of a Turkish University on Affective Commitment of Students". International Journal of Academic Research in Business and Social Sciences. Vol. 5 No. 11

Greenberg. 2016. Manajemen Kinerja. Bandung : PT Raja Grafindo Persada

Hamali, Arif Yusuf. 2016. Pemahaman Manajemen Sumber Daya Manusia. Yogyakarta: CAPS (Canter for Academic Publishing Service).

Handoko, T. H. 2015. Manajemen. Edisi 2. Yogyakarta: BPFE.

Harahap, Riri Ainun Mardiah dan Anita Silvianita. 2016. "Pengaruh Pelatihan Terhadap Kinerja Karyawan PT Pos Indonesia (Persero) Regional V Bandung". e-Proceeding of Management. Vol.3 No. 2

Hasibuan, S.P Malayu. 2016. Manajemen Sumber Daya Manusia. Jakarta: PT. Bumi Aksara. 
INOBIS: Jurnal Inovasi Bisnis dan Manajemen Indonesia

Volume 02, Nomor 02, Maret 2019

Muhammad Nashar, Sucses Rico Manurung

Jamaludin, Agus. 2017. "Pengaruh Gaya Kepemimpinan terhadap Kinerja Karyawan pada PT. Kaho Indahcitra Garment Jakarta”. Journal of Applied Business and Economics. Vol. 3 No. 3

Kaswan, Akhyadi. 2015. Pengembangan Sumber Daya Manusia. Bandung: Alfabeta.

Kurniawan DP. 2018. "Pengaruh Gaya Kepemimpinan terhadap Kinerja Karyawan Percetakan Dinas Kota Palembang”. Jurnal Ilmiah Manajemen Bisnis Dan Terapan. Vol. 15 No. 1

Mangkunegara, Anwar Prabu. 2017. Manajemen Sumber Daya Manusia. Bandung: PT. Remaja Rosdakarya.

Mangkunegara, Anwar Prabu. 2016. Manajemen Sumber Daya Manusia Perusahaan. Bandung : PT. Remaja Rosdakarya.

Mousavi, Sayede Ameneh., Ebrahim Albonaeimi., and Leila Andervazh. 2015. "Investigating the Factors Effect on Perceived Organizational Reputation in Organizations (Case Study: South West Power Generation Management Company) "Abadan Power Plant ". International Journal of Innovation and Research in Educational Science. Vol. 2 Issue. 5.

M Nashar, RD Parashakti, HS Fauziah. 2018. "Effect of Training and Job Performance on Job Satisfaction in PT Garuda Indonesia Training Center"Abadan Power Plant". Management Studies 6. No 4, 275-285.

Nguyen, By Nha and Gaston LeBlanc. 2018. "The Combined Effects of Service Offering and Service Employees on the Perceived Corporate Reputation”. Athens Journal of Business \& Economics. Vol. 4 Issue. 2

Pakpahan, Edi Saputra dan Siswidiyanto Sukanto. 2016. "Pengaruh Pendidikan dan Pelatihan terhadap Kinerja Pegawai (Studi pada Badan Kepegawaian Daerah Kota Malang)”. Jurnal Administrasi Publik. Vol. 2 No. 1.

Purba, Jon Henri. 2016. "Pengaruh Pelatihan dan gaya Kepemimpinan terhadap Kinerja Pegawai pada PT. Perkebunan Nusantara II Tanjung Morawa”. Jurnal Ilmiah Methonomi. Vol. 2 No. 2

Rivai, Veithzal. 2014. Manajemen Sumber Daya Manusia untuk Perusahaan. Edisi ke 6. Depok: PT. Raja Grafindo Persada.

Robbins, Stephen P and Timothy A. Judge 2015. Organizational Behavior. United State America: Pearson.

Rompas, Goverd Adler Clinton, Bernhard Tewal dan Lucky Dotulong. 2018. "Pengaruh Gaya Kepemimpinan, Pegawasan dan Disiplin Kerja terhadap Kinerja Pegawai pada Dinas Perhubungan Kabupaten Minahasa Tenggara”. Jurnal Emba. Vol. 6 No. 4.

Rozalena, Agustin dan Dewi, Sri Komala. 2016. Panduan Praktis Menyusun Pengembangan Karier Dan Pelatihan Karyawan. Edisi 1. Jakarta: Penebar Swadaya Grup.

Ruky, Ahmad S. 2016. Strategi, Kebijakan, dan Cara Penataan Upah, Gaji, dan Remunerasi. Jakarta: PT. Intipesan Pariwara.

RD Parashakti, A Haryadi, M Nashar. 2018. "Effect of Styles and Leadership Work Discipline to Employee Performance (Case Study of PT. Telecommunication Indonesia Tbk Dki Jakarta)". KnE Social Sciences 3 (10)

Saputro, Guntur Bayu dan Hotlan Siagian. 2017. "Pengaruh Gaya Kepemimpinan terhadap Kinerja Karyawan melalui Variabel Intervening Motivasi Kerja di Head Office PT. Marifood". Jurnal Agora. Vol. 5 No. 3

Sedarmayanti. 2017. Manajemen Sumber Daya Manusia. Reformasi Birokrasi dan Manajemen Pegawai Negeri Sipil. Cetakan Kelima. Bandung: PT Refika Aditama. 
Shahsavari, Azam and Mohammad Faryabi. 2015. "The Effect of Customer-Based Corporate Reputation on Customers' Citizenship Behaviors in Banking Industry". Research Journal of Applied Sciences, Engineering and Technology. Vol. 6 No. 20.

Shu, Efin and Daniel Cassa Augustinus. 2018. "Pengaruh Pelatihan terhadap Kinerja Karyawan pada Hotel Santika Premier Dyandra Medan”. Journal of Accounting \& Management Innovation. Vol. 2 No. 1.

Siagian, Sondang P. 2015. Manajemen Sumber Daya Manusia. Jakarta: Bumi Aksara.

Sinambela, Lijan Poltak. 2016. Manajemen Sumber Daya Manusia. Jakarta: PT Bumi Aksara

Simamora, Henry. 2014. Manajemen Sumberdaya Manusia. Yogyakarta: Sekolah Tinggi Ilmu Ekonomi YKPN.

Statsoft (2013). Structural Equation Modeling, Statsoft Electronic Statistics Textbook. http://www.statsoft.com/textbook/structural-equation-modeling/

Stavrinoudis, Theodoros and Dimitra Chrysanthopolou. 2015. "The role of leadership in building and managing corporate reputation of 4 and 5 star hotels". Tourism and Hospitality Research. Vol. 14 No. 1

Sudarmanto. 2015. Kinerja dan Pengembangan Kompetensi SDM. edisi tiga. Yogyakarta: Pustaka Pelajar.

Sugandi, Adi Jakaria dan Alini Gilang. 2017. "Pengaruh Gaya Kepemimpinan terhadap Kinerja Karyawan PT. Telkom Akses (PTTA) Jabar Tengah Divisi Provisioning”. $e$ Proceeding of Management. Vol. 4 No. 3.

Sugiyono. 2016. Metode Penelitian Kuantitatif Kualitataif dan Kombinasi (Mixed Methods). Bandung: Alfabeta.

Suher, Idil Karademirlidag., Cisil Sohodol Bir., and Ipek Gunes. 2017. "Employee's Perception of Corporate Reputation Management: a Research on a Turkish Leading Housing Firm". International Journal of Innovative Research and Development. Vol. 6 Issue. 2.

Sunyoto, Danang. 2015. Manajemen dan Pengembangan Sumber Daya Manusia. (Cetakan Pertama). Yogyakarta: CAPS (Center for Academic Publishing Service).

Sutrisno, Edy. 2016. Manajemen Sumber Daya Manusia. Cetakan ke-8. Jakarta : Prenada Media Group.

Terry, George R. 2016. Manajemen Sumber Daya Manusia. Jakarta : CV Haji Masagung.

Thamrin, Abdullah dan Francis Tantri. 2016. Manajemen Pemasaran. Depok : PT Raja Grafindo Persada

Tjiptono, Fandy. 2015. Strategi Pemasaran. Edisi 4. Yoyakarta: Penerbit Andi.

Tobari. 2015. Membangun budaya organisasi pada instansi pemerintahan. Yogyakarta: Penerbit Dee publish.

Wibowo. 2017. Perilaku Dalam Organisasi. Cetakan ketiga. Jakarta: PT. Raja Grafindo Persada

Widijanto, Kelvin Aldrian. 2017. "Pengaruh Pelatihan Kerja dan Motivasi Kerja terhadap Kinerja Karyawan Divisi Pemasaran di PT. Sumber Hasil Sejati Surabaya”. Jurnal Agora. Vol. 5 No. 1

Wirawan. 2015. Manajemen Sumber Daya Manusia Indonesia. Jakarta: PT Raja Grafindo Persada.

Yusuf, Hadijaya. 2015. Administrasi Pendidikan. Medan: Perdana Publishing 